\title{
An ECM Approach for Long Run Relationship Between Real Exchange Rate and Output Growth: Evidence from Bangladesh
}

\author{
Khnd. Md. Mostafa Kamal \\ Department of Statistics, Biostatistics and Informatics, Dhaka University, Dhaka-1000, Bangladesh
}

(Received: 03 November 2014; Accepted: 01 February 2015)

\begin{abstract}
Currency exchange rate is an important aspect in modern economy which indicates the strength of domestic currency with respect to international currency. This study uses 42 years' (1972 to 2013) time series data for Bangladesh in order to empirically determine whether the real exchange rate has significant impact on output growth for Bangladesh by using error correction model (ECM).The time series econometrics properties of the data series have been thoroughly investigated to apply ECM approach. The empirical evidence suggests mixed results; in the short run low exchange rate has positive significant effect while in the long run output growth is positively affected high exchange rate pass through.
\end{abstract}

Key Words: Real Exchange Rate, Output growth, ECM, Unit root, Cointegrated, Recursive estimate.

\section{Introduction}

International trade is one of the most important aspects of modern economic practices. The exchange rates of currencies lay at the heart of international trade as the subject matter. For this reason currency devaluation or depreciation sometimes considered as an important tool for improving the foreign sector of an economy considering the views of many economists, that the policies which encourage exports have a positive impact on economic growth. The relationship between the level of output and the real exchange rate is also an important controversial issue for economy. It is argued that depreciation of currency raises the price of import in comparison to that of its export and this causes the trade balance to improve which leads to an improvement in the foreign sector of the economy. This improvement in the foreign sector raises output and employment in the overall economy. According to traditional view of Keynesian economics devaluation or depreciation of currency have expansionary effect on output and aggregate demand.

On the other hand, contrary to traditional view, there are reasons for contractionary impact of currency devaluation on economy. According to Krugman and Tailor ${ }^{1}$ currency depreciation reallocates income from groups with a lower to a higher marginal propensity to save which may be the reason for decrease in aggregate demand output and employment in the overall economy. From another point of view, the currency devaluation decreases the aggregate demand though the negative real balance effect due to higher price level which in turn may decrease the output level and employment. Exchange rate depreciation raises the cost of imported inputs, leading to a decrease in aggregate supply. Additionally, exchange rate depreciation may raise the domestic interest rate and wage level through an increase in the price level which also may be a cause of decrease in aggregate supply.

Bangladesh economy faces a number of challenges stemming from both demand and supply sides. The highly volatile world price of oil causes considerable changes in the general price level in the country. Besides oil, Bangladesh has to import heavy machineries along with cereals to meet the demand for big-sized population. Increasing world prices of cereals and oil exert upward pressure on domestic inflation. Moreover, limited provision for industrial employment can absorb only a minor portion of labor force every year. However, the big portion of national income comes from readymade garments exports and from foreign remittances which is directly linked with BDT exchange rate against USD.

From June 2003 the central bank of Bangladesh, named Bangladesh Bank (BB), is following a floating exchange rate instead of fixed exchange rate regime that was practiced from 1972 to May 2003. Since the change in regime, the value of Bangladesh currency 'Taka' has fallen by more than $20 \%$ against the US Dollar during a period when the US Dollar itself has been losing value. The fact that even in the fixed regime, Bangladesh Bank followed an active exchange rate policy. Between 1983 and 2003, there have been as many as 89 adjustments in the value of Taka, 83 of which were devaluations and 6 of which were revaluations ${ }^{2}$.

In contrast, over the last years Bangladeshi taka (BDT) has continued to post strong gains against the United States Dollar (USD) although there was much variation in both GDP growth rate and currency depreciation rate at the very beginning (Fig 1). At the present time, it is expected that the BDT to extend gains into the next periods, supported by a rebound in the balance of payments (BoP); however, the pace of gains is expected to slow as Bangladesh Bank (BB) continues to build its foreign exchange reserves. In this context it is very important to know whether appreciation or depreciation or gaining strength of BDT against USD is good for econom1ic growth of Bangladesh.

The relationship between currency devaluation and growth has been investigated by different researchers having no consensus among their findings. The role of exports is vital in economic growth and especially the real exchange rate in export promotion features prominently in literature on development and globalization (Rodrik ${ }^{3}$, Haddad and Pancaro $^{4}$ ). Servén ${ }^{5}$ shows that the volatility of exchange rates has a negative impact on growth, investment and on exports of goods. However, Freund and Martha ${ }^{6}$ find large sustained depreciations of the real exchange rate, implying improvements in competitiveness. In some of their specifications they find that low levels of exchange rate volatility and high levels of trade openness significantly increase export. 


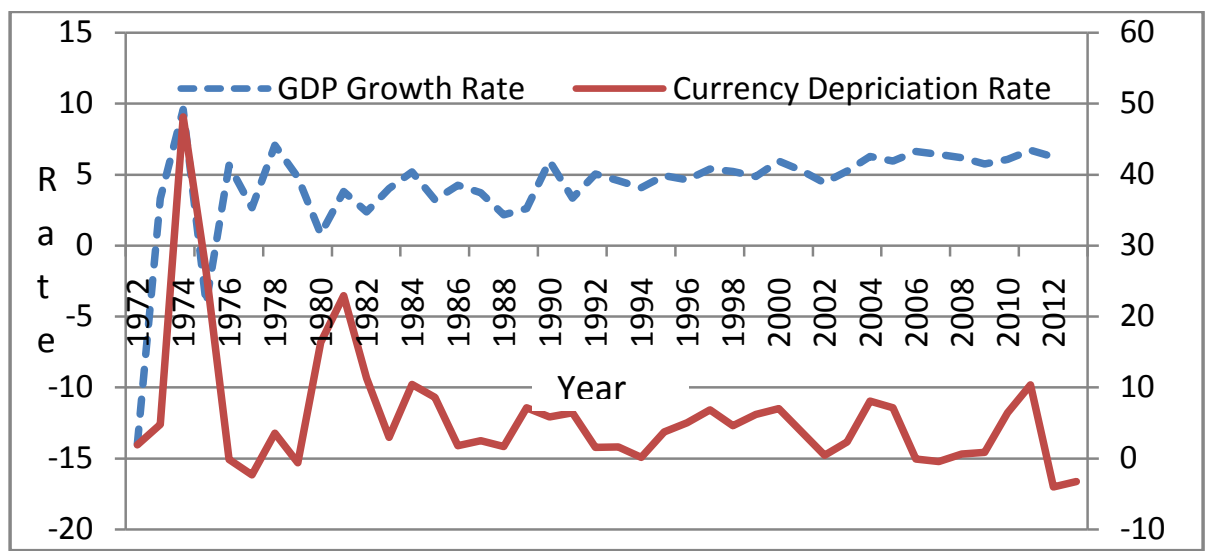

Fig. 1. GDP growth rate and exchange rate depreciation rate over time

Edward $^{7}$ claimed that devaluations had a negative effect on output in the short-run while they were neutral in the long run using pooled time series cross section data for 12 countries. This result was supported by Upadhyaya et.al. ${ }^{8}$ from the study of currency depreciation using panel data on Asian countries. While, Conoly, Schmid and Rosenweig ${ }^{9}$ found a positive relationship between currency devaluation and economic growth.

Eilat and Einav ${ }^{10}$ argue that the exchange rate matters more for exports and growth in advanced economies. In the context of developing-country, in contrast, the real exchange rate is likely to matter less, while political risk is more important for competitiveness in service sectors like tourism. In contrast, Goswami et. al. ${ }^{11}$ have found few differences in the determinants of services exports when they attempt to estimate the effect of currency devaluation on export separately for advanced and developing economies. The results from Eichengreen and Gupta ${ }^{12,}{ }^{13}$ confirm the importance of the real exchange rate for output growth. In addition, they find that the effect of the real exchange rate is even stronger for exports of services than exports of merchandise. It is especially large for exports of modern services, as opposed to traditional varieties. The evidence for differential effects between advanced and developing countries, in contrast, is weaker. Still, this suggests that as developing countries shift from exporting primarily commodities and merchandise to exporting traditional and modern services, appropriate policies toward the real exchange rate became even more important.

The above mentioned studies have been done by considering either panel data or time series over some specific period of some region or some selected countries. While no such study for the effect of currency devaluation on economic growth was conducted for Bangladesh. This study is using Error Correction Mechanism to find the long run relationship between currency exchange rate condition and output growth for Bangladesh economy. The outcome of the research will guide the monetary authority as well as fiscal authority in determining the appropriate policy rule regarding the exchange rate pass through.

\section{Data and Variables}

To establish the relationship between exchange rate and output growth, two variables namely Real Gross Domestic Product (GDP) and Real Exchange rate (RER) have been used. The real exchange rate is defined as nominal exchange rate (national currency per USD) times the ratio of US price index to the domestic consumer price index (CPI). All series are expressed in logarithm. Data on GDP and nominal exchange rate from year 1972 to 2013 have been collected from the Bangladesh chapter of the World Bank economic indicator data. CPI data from year 1986 to 2013 have been taken from the same source. CPI data from year 1972 to 1985 are not available there; data for this period have been taken from Bangladesh bureau of statistics where consumer price index is considered for government employees only. But this group can be consisted as the representative group for the entire population. Data on US price index for the entire period have been taken from the St Luis Federal Reserve Bank data source.

\section{Methodology}

To justify the effect of exchange rate on output the following simple regression model has been employed following Christopoluos (2004) method: $\log \left(\mathrm{GDP}_{\mathrm{t}}\right)=\alpha+\beta \log \left(R E R_{t}\right)+u_{t}$; Where, GDP indicates the real gross domestic product evaluated at constant price, RER denotes the real exchange rate. Since both series are expressed in logarithm form, the coefficient $\beta$ measures the elasticity of GDP with respect to RER. If the estimated coefficient $\beta$ is positive and statistically significant, then it could be said that exchange rate depreciation is expansionary to the economy.

On the other hand if the estimated coefficient $\beta$ has statistically significant negative effect on real GDP then it could be said that exchange rate depreciation is contractionary to the economy. If the estimated coefficient $\beta$ has no statistical significant effect on real GDP then it could be say that the exchange rate is neutral to real GDP that is exchange rate is neither contractionary nor expansionary to the economy. 
As this empirical work is dealing with time series data, before estimating the regression model time series properties of the data series should be checked. Because regression results are valid if the data series possess stationarity. On the other hand if the series are not stationary then cointegration test should be employed. Firstly, to check whether the data series are stationary or not; Augmented Dickey-Fuller (ADF) unit root test where the null hypothesis is that the series possesses unit root should be applied. The present study uses the ADF test which includes constant and trend.

Having established that all variables are integrated of the same order cointegration test is the appropriate method for detecting the existence of long run relationship. Engle and granger ${ }^{14}$ (1987) argue that, even though a set of economic series is not stationary, there may exist some linear combinations of the variables that are stationary. If the separate series are stationary only after differencing but a linear combination of their levels is stationary, the series are cointegrated. If the variables in the model are found to be Cointegrated following Engle and Granger (1987) an error correction model (ECM) is developed to account for short run effect.
$\Delta \log G D P_{t}=\beta_{0}+\sum_{i=1}^{n} \beta_{1} \Delta \log G D P_{t-i}+$

$\sum_{i=o}^{n} \beta_{2} \Delta \log R E R_{t-i}+\beta_{3} E C_{t-1}+v_{t} ;$ Where EC represents the equilibrium error that is the deviation from the long-run relationship, $\Delta$ is the first difference operator, $v$ is the statistical noise; $\beta_{0}, \beta_{1}, \beta_{2}$ , $\beta_{3}$ are parameters to be estimated.

\section{Estimation}

At first, the time series properties of each series should be investigated. Fig 2 clearly shows that there exist trend in series, the real GDP growth rate has strict positive trend while the real exchange rate possesses volatility, although the volatility was higher at the beginning. Therefore to justify the existence of unit root in each series the ADF test on the levels, first differences and second differences of the variables have been employed and the test results are presented in table1.

Table 1 shows the ADF test statistic, corresponding probability values of rejecting null hypothesis and associated lag orders. Lag orders are determined on the basis of Schwarz Information Criterion (SIC).

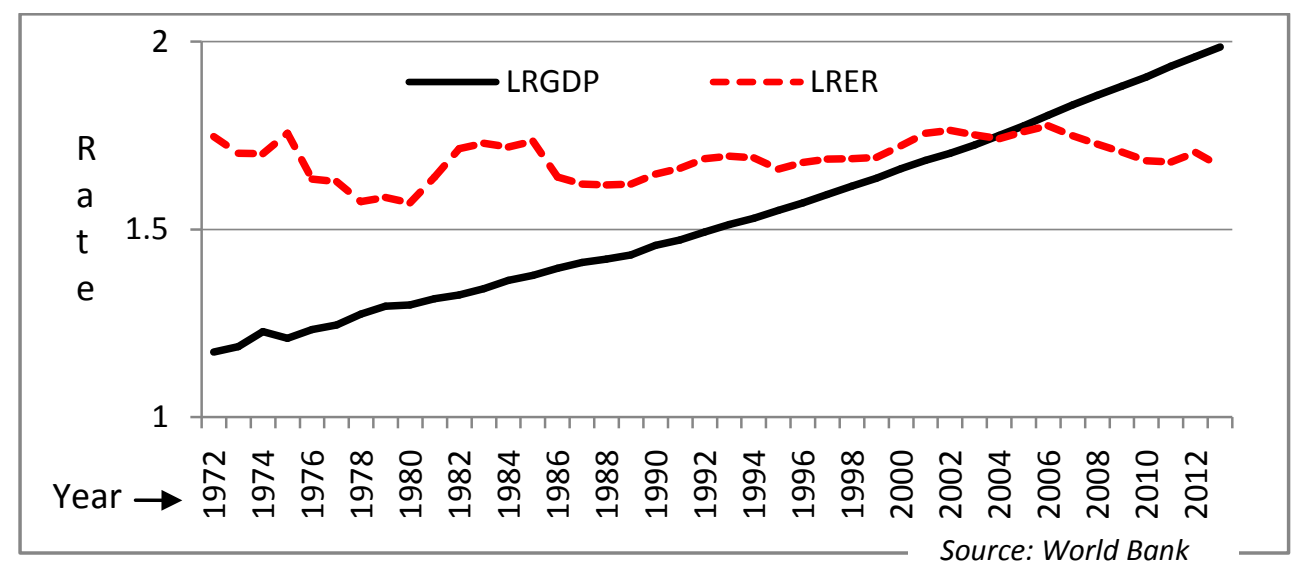

Fig. 2. Real GDP growth rate and real exchange rate over time

Table 1. Augmented Dickey- Fuller (ADF) unit root test results

\begin{tabular}{|c|c|c|c|c|c|c|}
\hline & \multicolumn{2}{|l|}{ level } & \multicolumn{2}{|c|}{ First difference } & \multicolumn{2}{|c|}{ Second difference } \\
\hline & Ln(RGDP) & Ln(RER) & Ln(RGDP) & Ln(RER) & Ln(RGDP) & Ln(RER) \\
\hline ADF [prob] & $3.07[0.93]$ & $-2.38[0.15]$ & $-2.75[0.08]$ & $-3.01[0.04]$ & $-9.70[0.00]$ & $10.8[0.00]$ \\
\hline Lag order & 0 & 1 & 2 & 0 & 1 & 0 \\
\hline
\end{tabular}

Note: ADF test for a unit root in the model with constant. The critical values for ADF test are $-3.60,-2.94$ and 2.61 at $1 \%$, 5\% and $10 \%$ level of significance respectively. Square bracket shows the probability of rejecting null hypothesis. 


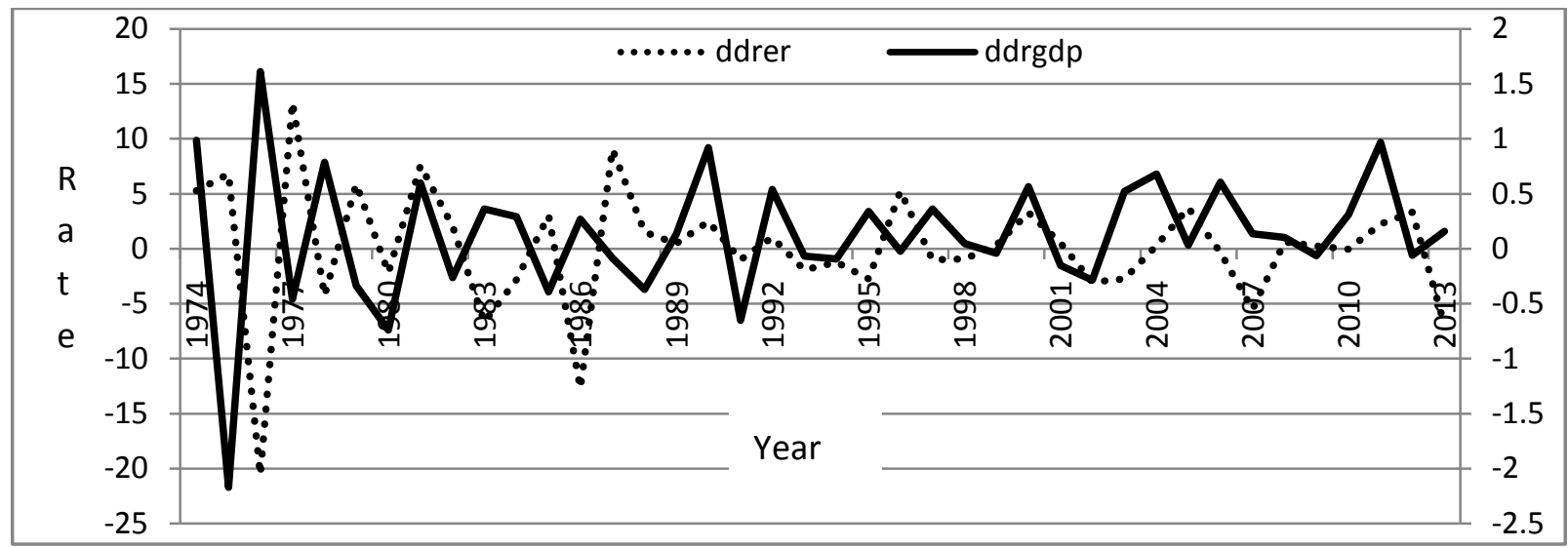

Fig. 3. Graphical plot of second difference in real GDP series and real exchange rate

The result in Table1 show that all series have unit roots in their levels and in first difference as well (ADF statistic are less than critical values, so the null hypothesis of unit root cannot be rejected), but no unit root in the second difference of both series. Therefore, considering the second difference (variables are symbolically represented as ddrer and ddrgdp) it could be said that all the series are integrated of order two i.e. I (2). Thus, according to Enders ${ }^{15}$, the two series share a long-run relationship. These results are also supported by Fig 3.

After finding that all variables are cointegrated of second order, now Engle - Granger cointegration test can be safely used for detecting the existence of long run relationship. Engle- Granger cointegration test results where null hypothesis is series are not co-integrated are presented in Table2.
From table 2, the Engle-Granger Cointegration test result confirms the presence of a long run equilibrium relationship between real exchange rate and real GDP. The Tau-statistic and Z-statistic based on Mackinnon ${ }^{16}$ rejects the null hypothesis of no cointegrated relationship between real GDP and real exchange rate in their second difference.

At the same line the unit roots test using t-test, ADF test, PP- Fisher test and W-test all suggest that the null hypothesis of no cointegration can be rejected at any level of significance, therefore the respective residuals could be safely used as error correction term. Lag order was determined using Swartz Information Criterion. Johnson cointegration test results in Table 2 indicate that currency devaluation exerts a negative impact on output expansion and coefficient of real exchange rate is statistically significant.

Table 2. Engle-Granger co-integration test results

\begin{tabular}{|c|c|c|c|}
\hline & \multicolumn{2}{|r|}{ Statistic } & \multirow[t]{2}{*}{ p-values } \\
\hline & Tau-statistic & z-statistic & \\
\hline DDRGDP & -10.62 & -56.54 & $\mathbf{0 . 0 0}$ \\
\hline DDRER & -9.31 & -53.76 & 0.00 \\
\hline \multicolumn{4}{|c|}{ Unit root test( Null hypothesis: common unit root process) } \\
\hline Levin, Lin \& Chu $t^{*}$ statistic: & & -17.47 & 0.000 \\
\hline \multicolumn{4}{|c|}{ Unit root test Null: Unit root (assumes individual unit root process) } \\
\hline ADF - Fisher Chi-square statistic & & 83.7240 & 0.000 \\
\hline PP - Fisher Chi-square statistic & & 58.6329 & 0.000 \\
\hline LM, Pesaran and Shin W-statistic & & -16.0722 & 0.000 \\
\hline \multicolumn{4}{|l|}{ Lag order: 0} \\
\hline \multicolumn{4}{|c|}{ Johnson co-integration test } \\
\hline constant & \multicolumn{3}{|l|}{ DDRER } \\
\hline $0.12(0.09)$ & \multicolumn{3}{|l|}{$-0.042(0.016)$} \\
\hline
\end{tabular}

Notes: number inside square bracket next to each coefficient is the standard error. Number inside parentheses in front of ADF statistic is lag order which was determined by SIC. ADF test for a unit root in the model no constant/no trend. The critical values for ADF tests are 1.94,-2.58 and -1.62 for 5\%, 1\% and 10\% respectively. Reported first two P-values are Mackinnon (1996) p- values. 
All these tests ensure the applicability of ECM approach toward the Bangladesh economy to establish the long run relationship between exchange rate pass through and output growth. Establishing that the variables are found to be cointegrated, an error correction model is estimated to account for a short run effect and the results of Estimated Error Correction Model (ECM) are presented in Table3. The models have been estimated by OLS until the year 2009 and remaining 4 years i.e. from 2010 to 2013 have been set for forecasting performance. Estimated models are free from the problem of autocorrelation and heteroskedasticity and the coefficients are statistically highly significant. The estimated result of $\mathrm{R}^{2}$ demonstrates that $68 \%$ variation of exchange rate instability can be clarified though this ECM Model which is statistically significant as well. These results illustrate that the ECM model is statistically significant to capture the internal variation within the data series.

\section{Table 3. Test results for error correction}

\begin{tabular}{|c|c|c|c|c|c|}
\hline Constant & DDLRER $_{\mathrm{t}}$ & DDLRER $_{\mathrm{t}-1}$ & $\mathrm{EC}_{\mathrm{t}}$ & $\mathrm{EC}_{\mathrm{t}-1}$ & $\mathrm{R}^{2}$ \\
\hline $0.00049(0.001)$ & $0.62 *(0.22)$ & $-0.047^{*}$ & $0.003^{*}(0.001)$ & $-0.007 *$ & 0.68 \\
& & $(0.02)$ & & $(0.002)$ & \\
\hline
\end{tabular}

Notes: Standard errors are in square bracket next to coefficients. * indicates statistically significant at $1 \%$.
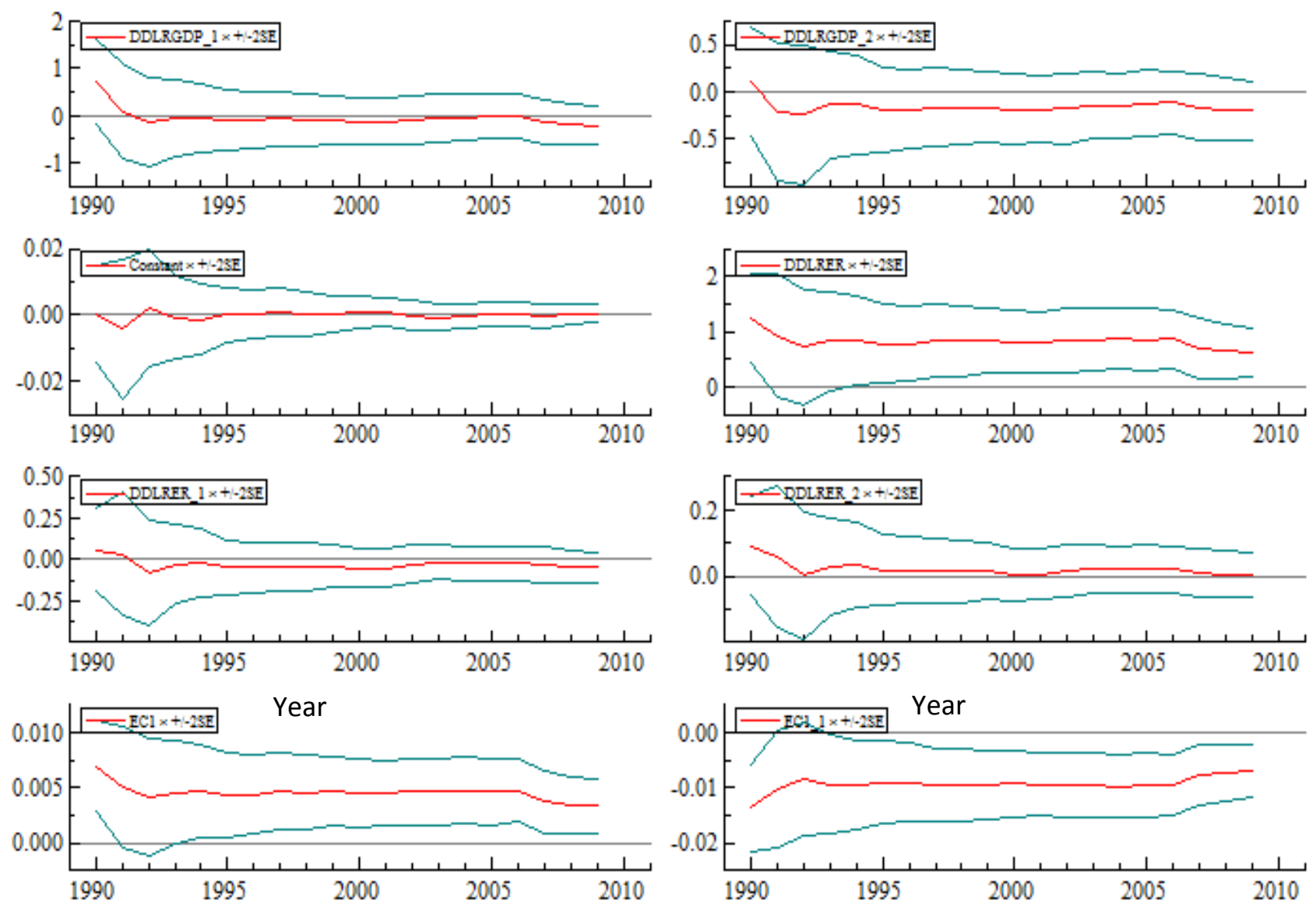

Fig. 4. Graphs for Recursive Estimates of the ECM parameters [Y-axis represents the coefficients with confidence limit at each recursion]

Figure 4 shows that parameter estimates are very stable and the $95 \%$ confidence interval (CI) is very small. As a result, the estimated coefficients can safely be considered. From the parameter estimates it could be said that the depreciation has immediate positive significant effect on output while this effect is not negative for a long run. The estimated error correction term has exactly same behavior like the real exchange rate. The behavior is such due to a large remittance. When there exist currency devaluation then immediately remittance receiver earns substantial amount of money, but due to lower value of BDT it decreases the purchase power. 


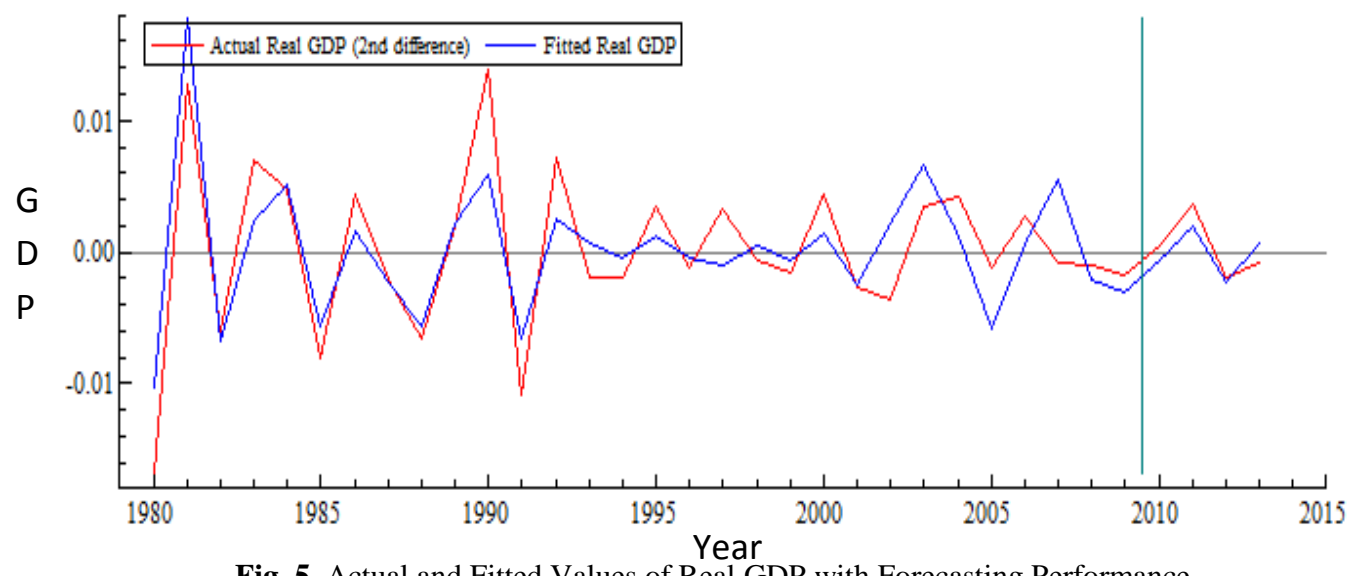

Fig. 5. Actual and Fitted Values of Real GDP with Forecasting Performance.

(Note: Vertical line corresponding to the year 2010 separates the prediction part from estimated part)

Figure 5 shows that the estimated model fits nicely, forecasts do not deviate systematically and the residuals lay in the range -0.01 to 0.01 . For the forecast period i.e. from year 2009 to 2013 fitted value has exactly same direction as the actual values of GDP series. This is also true for earlier period as well. Therefore, the model could easily be used for further forecasting.

\section{Conclusion}

This research paper aims to explore the long run and short run effect of real exchange rate depreciation on output for Bangladesh. The unit root test, Engle Granger cointegration and Johnson's cointegration test were employed to scrutinize the properties of these variables over time. The unit root test and the Engle - Granger test results confirm that the data series are integrated of second order. Finally, an error correction model is employed. The analysis suggests mixed results. In the long run, currency devaluation has negative impact on output while this impact is positive in the short run. Therefore, the policy makers should be cautious in frequent currency devaluation aiming to increase output growth. For short run gaining Currency may be depreciated. But if the long run output expansion is the ultimate goal, local currency should continue with its strong position against international currencies.

\section{References}

1. Krugman, P. and L. Taylor, 1978. Contractionary effect of devaluation. Journal of International Economics. 18, 445-56.

2. Islam, M. A., 2003. Exchange Rate Policy of Bangladesh: Not Floating Does Not Mean Sinking. Center of Policy Dialogue (CPD) Occasional Paper series, 20.

3. Rodrik, D., 2009. The Real Exchange Rate and Economic Growth. Brookings Papers on Economic Activity. 1, 365-412.

4. Haddad M. and C. Pancaro, 2010. Can Real Exchange Rate Undervaluation Boost Exports and Growth in Developing Countries? Yes, But Not for Long. Economic Premise 20, World Bank PREM Network, June.
5. Servén L. 2003. Real Exchange Rate Uncertainty and Private Investment in LDCs. Review of Economics and Statistics 85, 492-492.

6. Freund C. and M. D. Pierola, 2012. "Export Surges," Journal of Development Economics. 97, 387-395.

7. Edwards S. 1986. Are Devaluations Contractionary? The Review of Economics and Statistics, 68, 501-7.

8. Upadhyaya, K.P., F.G. Mixon, R. Bhandari, 2004. "Exchange rate adjustment and output in Greece and Cyprus: evidence from panel data. Applied Financial Economics, 14, 1181-1185.

9. Connolly, M., 1983. Exchange Rates, Real Economic Activity and the Balance of Payments: Evidence from the 1960s. In E. Classen and P. Salin, eds., Recent Issues in the Theory of the Flexible Exchange Rates. Amsterdam, Holland.

10. Eilat, Y. and L. Einav 2004. The Determinants of International Tourism: A Three- Dimensional Panel Data Analysis. Applied Economics. 36, 1315-1327.

11. Goswami A., A. Mattoo, and S. Saez, 2012.Exporting Services: A Developing Country Perspective, Washington D.C.The World Bank, 1-24.

12. Eichengreen, B. and P. Gupta, 2012. The Real Exchange Rate and Export Growth: Are Services Different? NIPFP Working Paper 112.

13. Eichengreen B. and P. Gupta, 2011. The Service Sector as India's Road to Economic Growth. India Policy Forum 7, National Council of Applied Economic Research (NCAER), New Delhi, and the Brookings Institution, Washington D.C.

14. Engle, R.F. and C.W.J Granger, 1987. Co-integration and error correction: representation, estimation and testing. Econometrica. 55, 251-76.

15. Enders, Walter, 2004. Cointegration and Error-Correction Models". Applied Econometrics Time Series (Second ed.). New York: Wiley. 319-386.

16. Mackinnon J.G., 1996. Numerical Distribution functions for unit root and cointegration test. Journal of Applied Econometrics.11, 601-618. 